\title{
The Impact of Perceived Training Utility on Transfer of Training: The medi- ating role of Motivation to Transfer
}

\author{
Kamran Iqbal*, Dr. Muhammad Arif, Muhammad Sarwar Zahid \\ Bahria University, Islamabad, Pakistan
}

\begin{abstract}
The purpose of this study was to examine the mediating role of motivation between the relationship of perceived training utility and transfer of training. Data were obtained from 215 employees working in the banking sector. SPSS and AMOS statistical software were used to test the hypothesized model. Consistent with social cognitive theory, results suggested a significant positive relationship of perceived training utility with motivation to transfer and transfer of training. The results further revealed that the relationship between perceived training utility and transfer of training had an indirect effect via Motivation to transfer. This study has made a significant theoretical contribution to the literature by exploring the mechanism through which perceived training utility affects transfer of training. This study will help HRD professionals to understand the importance of perceived training utility in transfer of training.
\end{abstract}

\section{Introduction}

Training has been used as one of the important tools for improvement of overall performance and productivity of employees (Bhatti and Kaur, 2009). Training is designed in order to improve the job-related competencies of employees. Due to rapid changes in technology and globalization, continuous changes have occurred in the business organizations, every organization is striving to gain competitive advantage through the development of Knowledge, skills and abilities in their employees. Organizations consider human capital as one of the most important asset, which is required to maintain sustainable competitive advantage. Organizations invest heavy budget on the training of their employees as it serves as a powerful tool for desired behavioral changes and outcomes required for their existence (Salas and Stagl, 2009). Human capital theory posits that education helps to improve existing KSA, which make employees more productive (Becker et al., 1964). Burke et al. (2006) defined training as systematic acquisition of knowledge, skills and attitudes that together lead to improved performance in a specific environment. Training is considered as leading opportunity for all employees to expand their knowledge. Organization can get benefits from training in term of employees outcomes i.e. job attitude and organizational outcomes, i.e. organizational performance (Tharenou et al., 2007). But training cannot produce positive outcomes unless and until newly learned skills are transferred to an actual job (Montesino, 2002). Blume et al.

*Corresponding author.

Email: sgd.kamran@gmail.com
(2010) has defined training transfer as the extent to which knowledge and skill acquired in a learning setting can be applied in the workplace, and maintained over time. Burke and Hutchins (2007) found that 1040 percent of training usually transfers to the actual job. Kirkpatrick and Davis (1994) mentioned transfer of training as a key criterion for evaluation of training effectiveness. In Pakistan, State Bank of Pakistan (SBP) regulate the financial sector. It provides detailed guidelines for structural reforms to fulfill overall social and economic requirements. According to SBP annual performance review (2007), SBP undergoes restructuring of its human resource in order to improve standards for its services. In banking industry of Pakistan, Management development programs are an integral part of overall development plans of all banks of Pakistan (Dastgeer and ur Rehman, 2012).

Although abundant literature is available on perceived training utility, motivation to transfer and transfer of training, but no study is available that explored the relationship between perceived training utility, motivation to transfer and training transfer in one study. Our contribution to the literature of transfer of training is not only to explore the link between perceived training utility and transfer of training but also how and why motivation works as a bridge in this link.

\section{Literature Review}

Research has pointed three main predictors of transfer of training: employees characteristics, train- 
ing design and working environment (Baldwin and Ford, 1988; Burke and Hutchins, 2007; Lim and Johnson, 2002; March and Olsen, 1998; Schwab et al., 2010). In literature related to training, transfer of training has grabbed the attention of a great number of scholars and professionals. Kirkpatrick and Davis (1994) training four level models demonstrate that transfer of training helps employees and organizations to achieve their performance related goals.

\subsection{Relationship between Perceived Train- ing Utility and Transfer of Training}

Training plays a significant role in enhancing employee job performance which ultimately leads to organizational development. Training result in improved employee performance, however, training effectiveness depends on the participants perception. The perceived training utility is also an important predictor of transfer of training. The perceived utility is conducive due to the fact that if trainees do not understand the utility attached with particular training, then more chances that trainees will not take training as a useful activity to improve their job. Hence, less perceived utility will directly affect the employees job performance and vice versa. Going ahead, the trainees utility perception might change with time and working environment (Chiaburu and Lindsay, 2008). Organizational support theory posits that when employees feel that their efforts are not considered or valued by their organizations, then more likely they will not put serious effort for organizational benefits (Kontoghiorghes, 2001). Furthermore, Clark and Mils (1993), posit that perceived utility training is directly related to trainees perception about training effectiveness to their career or job utility. Clark and Mils (1993) defined Career utility as the perceived usefulness of training for attainment of career goals, such as getting a raise or promotion, or taking a more fulfilling job, whereas, Job utility was defined as the perceived usefulness of the training course to facilitate goals associated with the current job, such as increased productivity, reduced errors, or better problem-solving skills. Training utility is considered as an important element while studying transfer of training. Perceived training utility has a significant effect on transfer of training (Burke and Hutchins, 2007). Chiaburu and Lindsay (2008) established that perception of trainees about the utility of training mainly depend on the relationship between training and expected outcomes. Chiaburu and Lindsay (2008) conducted their research on the topic related to training transfer on employees of big organizations in the service sector of USA and observed a strong relationship between perceived training utility and transfer of training. Grossman and Salas (2011) also found linkage between training utility and motivation to transfer.
Expectancy model could be useful to understand the role of motivation in transfer of training (Baldwin and Ford, 1988). An individual put efforts when he expects positive outcomes, and if a person lacks in positive expectation, it would be least likely that he will put efforts for performance improvement (Vroom, 1964). The concept of perceived training utility can also be understood with the help of expectancy theory. Research has found that trainees with positive expectation from particular training were more motivated to apply their KSAs on actual work (Grossman and Salas, 2011).

\subsection{Motivation to Transfer as a Mediator}

Although there are certain factors that affect transfer of training such as job control (Gijbels et al., 2010), a feasible work climate (Harteis and Gruber, 2004) and interest (Lewalter and Scholta, 2009) but motivation is considered as most worthy element for training transfer as suggested by Latham and Locke (2007), as the time, money, and resources an organization devotes to ways of increasing a persons abilities are wasted to the extent that an employee chooses not to learn what is being taught, or chooses not to apply newly acquired knowledge and skills in the workplace(p. 3) Motivation to transfer is defined byBates (2007) as the direction, intensity and persistence of effort towards utilizing in a work setting the skills and knowledge learned during the training program. Its a trainees desire to apply learned KSA on actual work (Noe and Schmitt, 1986) Research on motivation to transfer has gained popularity among the researchers in recent years (Segers and Gegenfurtner, 2013). Axtell et al. (1997) in their study found that transfer motivation has a strong influence on transfer of training for up to 1 year of duration after training. If Trainees perceive that their performance level will be improved by the using KSA which they will learn during the training program, they will put extra efforts to learn new skills and after learning, apply those skills on actual job.

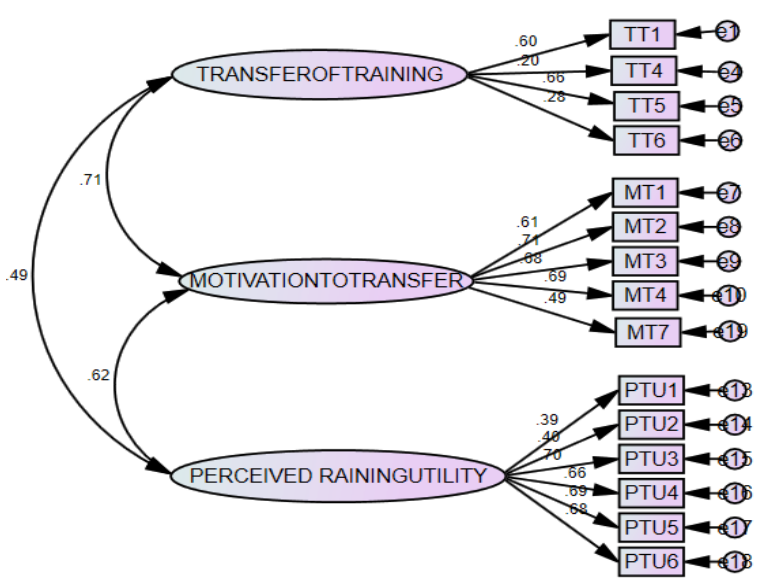


On the basis of above literature the following hypotheses have been proposed:

H1: Perceived training utility is positively related to motivation to transfer.

H2: Motivation to transfer is positively related to transfer of training.

H3: Perceived training utility is positively related to transfer of training.

H4: Motivation to transfer mediates the relationship between Perceived training utility and transfer of training.

\section{Theoretical Framework}

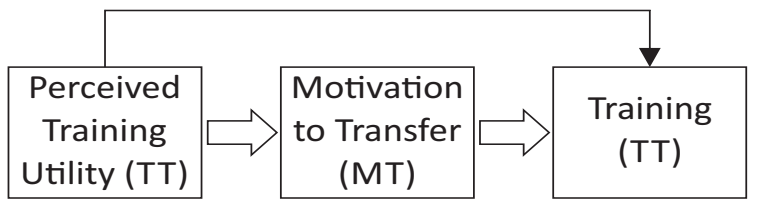

Figure 1: Theoretical Model

\section{Methodology}

The data of this study were collected from the employee of private banks in Pakistan. Judgmental nonprobability sampling technique was employed to select the sample. The survey was personally administered by the researcher himself. Researcher had got approval from branch manager of every bank before distribution of questionnaires to specific branch staff in order to avoid any inconvenience during data collection. A brief description of the study was attached at the start of the questionnaire to describe the aim and background of the study. In addition, assurance of confidentiality was highlighted to the respondents.Sekaran and Bougie (2010) mentioned that this approach is useful to clarify the doubts of the respondents, which result in high response rate. Total about 300 questionnaires were circulated, but only $215(72 \%)$ were finally used for the analysis. All questionnaires were adopted from previous studies. Perceived training utility was adopted from Van Eerde et al. (2008) questionnaire containing six items, sample item, The time spent away from the job to attend training has been worthwhile. The value of Cronbach's Alpha was .756 for this variable. The Questionnaire of transfer of training was adopted from Xiao et al. (1996), containing six items, i.e. I can accomplish the tasks better by using the new knowledge acquired from the training course. The value of Cronbach's Alpha was .622 for this variable. The questionnaire of Motivation to transfer was adopted from
Holton et al. (1997), containing five items i.e., I am thinking about trying to use my new learning on my job. The value of Cronbach's Alpha was .767 for this variable. For all variable Five points Likert scale from strongly agree $=5$ to strongly disagree $=1$ was used to collect the responses.

The sample consists of $62.8 \%$ males and $37.2 \%$ females. Out of total respondents, $47.44 \%$ are married and $52.66 \%$ are Un-married. Most respondents have 14 years of education (B.Com/BA/B.Sc) with $51.6 \%$, followed by $45.1 \%$ with an education of 16 years and above, while only $2.8 \%$ of the respondents have 12 years of education. Out of 215 respondents, total of $24.7 \%$ have age less than 25 , while most of the respondents $(63.7 \%)$ having ages between 25 to 35 . Out of total sample, $38.6 \%$ have organizational tenure of 1 or less, $48.8 \%$ between 2 to 7 years, and $9.3 \%$ between 8 to 13 years, while only $1.9 \%$ with 14 or above organizational tenure. Out of total sample $20.5 \%$ have organizational tenure 1 or less, $25.6 \%$ between 2 to 7 years, and $24 \%$ between $8-13$, while only $9.3 \%$ with 14 or above years job tenure. Out of total respondents, $57.7 \%$ were middle-level employees, $24.7 \%$ managerial level employees, while only $16.7 \%$ were lower level employees.

\section{Results}

\subsection{Confirmatory Factor Analysis}

AMOS statistical software was employed to run confirmatory factor analysis (CFA) to verify the uniqueness of the variables. The figure given under table 1 presents the factor loading of the variables used in the study. All ill loaded items have been deleted. CFA revealed that perceived training utility was adequately measured with six items, motivation to transfer with five items, transfer of training with four items. The results of the CFA show that 2/df value 192.821 has a good fit with other indices GFI (.891), AGFI (.849), and CFI (.864) indicating good fit. The value of RMSEA is 0.075 which is considered as acceptable as its value is less than 0.08. (RMSEA) is 0.075 which is considered as acceptable as its value is less than 0.08 .

\subsection{Correlation analysis}

Table 2 shows the level of correlation which exists between the variables of the current study. Results show that all variables are highly correlated. Correlation analysis exhibits that highest correlation is present between perceived training utility and motivation to transfer $(\mathrm{r}=.506, \mathrm{p}<.01)$, followed by correlation between motivation to transfer and transfer of training $(\mathrm{r}=.395, \mathrm{p}<.01)$, and between perceived training utility and transfer of training $(\mathrm{r}=.267, \mathrm{p}<.05)$. 


\subsection{Regression Analyses}

Table 3 shows that perceived training utility has an estimated regression weight of 0.631 ( $p \leq 0.005)$ on motivation to transfer. So our hypothesis $\mathrm{H} 1$ has been accepted, which indicates that perceived training utility has a positive impact on motivation to transfer. Motivation to transfer has an estimated regression weight of 0.529 ( $p \leq 0.01$ ) on transfer of training, leading to acceptance of hypothesis 2 . Similarly, perceived training utility has an estimated regression weight of 0.361 ( $\mathrm{p} \leq$ 0.01) on transfer of training, so our hypothesis 3 has also been accepted, indicating that perceived training utility is positively associated with transfer of training. In order to check the mediating role of motivation to transfer between the relationship of perceived training utility and transfer of training, two models have been compared; first, without any mediating variable and then along with the mediating variable. Results show that when the model was run in presence of mediators, relationship between training utility and transfer of training became non-significant. This shows that motivation to transfer mediates the relationship between perceived training utility and transfer of training according to Baron and Kenny (1986). Hence hypothesis four has also been accepted.
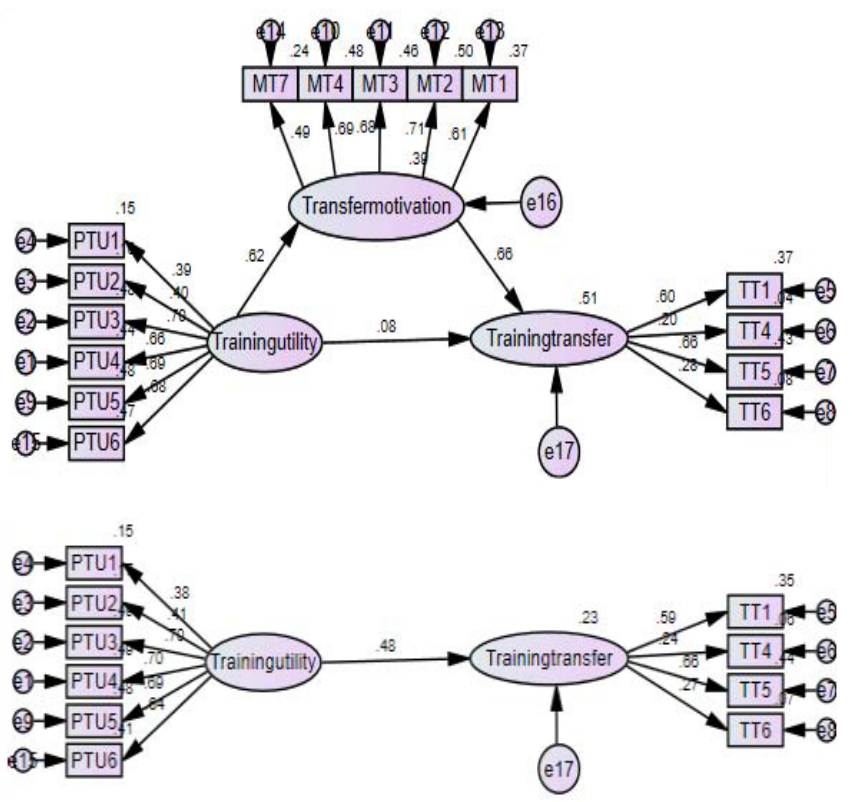

Table 1: Index of fit of the Model

\section{Discussion}

The purpose of the current study was to examine the linkage between perceived training utility and transfer of training through the mediation of motivation to transfer. The study consists of four hypotheses. The first hypothesis stated that Perceived training utility is positively related to motivation to transfer. Regression results show positive association between perceived training utility and transfer of training $(\beta=0.631, \mathrm{p}<.001)$, which are consistent with the past studies (Alliger et al., 1997; Burke and Hutchins, 2007; Chiaburu and Lindsay, 2008). The hypothesis two stated that Motivation to transfer is positively related to transfer of training, results indicate a positive association between motivation to transfer and transfer of training $(\beta=0.529, \mathrm{p}<.001)$ which is consistent with the past studies (Clark and Mils, 1993; Grossman and Salas, 2011). Similarly, hypothesis 3 tested that Perceived training utility is positively related to transfer of training. Regression analysis indicates a positive association between perceived training utility and transfer of training $(=0.361, \mathrm{p}<.001)$ which is also consistent with the past studies (Bhatti and Kaur, 2009; Kirwan and Birchall, 2006; Liebermann and Hoffmann, 2008; Nikandrou et al., 2009). For testing the hypothesis $\mathrm{H} 4$ which stated that Motivation to transfer mediates the relationship between Perceived training utility and transfer of training, Barron \& Kenny (1986) mediation technique was employed by using AMOS software. Results indicated that motivation to transfer mediates the relationship between perceived training utility and transfer of training, therefore, leading to the acceptance of hypothesis four as well. This shows that employees perception about the benefits from a training program plays a key role in motivation to transfer which in turn increase transfer of training.

\subsection{Implications and Recommendations}

Training is considered as most suitable way to improve KSA of employees through their differentiation in the KSA of their human resource. But organizations can only get benefits from their training if trainees put their efforts to transfer learned skills on the actual job. The findings of the present study suggest that perceived training utility and motivation to transfer are the important predictors of transfer of training. The second major finding of the study is that Motivation to

Fit Measures

\begin{tabular}{ccccccccc} 
& Chi-Square & DF & p value & CMIN/DF & GFI & CFI & AGFI & RMSEA \\
\hline Values & 192.821 & 87 & 0.000 & 2.216 & 0.891 & 0.864 & 0.849 & 0.075 \\
\hline
\end{tabular}


Table 2: Descriptive statistics and inter-correlations for all study variables

\begin{tabular}{lccccc}
\hline Variables & Mean & Std. Deviation & PTU & MT & TT \\
\hline Perceived training utility (PTU) & 3.807 & 0.57155 & 1 & & \\
Motivation to transfer (MT) & 3.9684 & 0.58878 & $.506^{* *}$ & 1 & \\
Transfer of training (TT) & 3.6616 & 0.58384 & $.267^{*}$ & $.395^{* *}$ & 1 \\
\hline
\end{tabular}

${ }^{* * *}$ Correlation is significant at .01 levels (two tailed) N: 215

${ }^{* *}$ Correlation is significant at .05 levels (two tailed)

Table 3: Hypotheses testing based on regression weights

\begin{tabular}{lccccc}
\hline Variables & Estimates & S.E. & Critical ratio & P value & Results \\
\hline MT $\leftarrow$ PTU & 0.631 & 0.104 & 6.068 & $* * *$ & Accepted \\
TT $\leftarrow$ MT & 0.529 & 0.123 & 4.31 & $* * *$ & Accepted \\
TT $\leftarrow$ PTU & 0.361 & 0.095 & 3.957 & $* * *$ & Accepted \\
TT $\leftarrow$ MT $\leftarrow$ PTU & 0.067 & 0.103 & 0.648 & 0.517 & Full mediation \\
\hline${ }_{* * *}^{*}$ P value significant at .01 & & & & &
\end{tabular}

transfer mediates the relationship between perceived training utility. Therefore, to increase transfer of training, perceived training utility and motivation to transfer should be taken as important factors. The present study recommends policy maker of banking sector of Pakistan to understand the impact of perceived training utility on the motivation of employees related to transference of learned KSA on an actual job. This study concluded that perception about the benefits attached to a particular training has significant impact on the motivation to transfer and transfer of training. So employees should be communicated well, on how particular training will be beneficial for their job performance and long term career growth.

\subsection{Future Directions}

Firstly, the current study only examined the temporal effect of perceived utility on transfer training however, the future studies should examine how perceived utility changes with time. Secondly, the current study takes the banking sector as a contextual setting. Future study may use various other organizational settings to increase the generalizability of the findings. Thirdly, this study used a cross-sectional survey to test the hypotheses of the study. However, future researchers may use a longitudinal technique, also, mixed methodology may be used. Lastly, this study took motivation as one variable; researchers may test different dimensions of motivation to transfer as suggested by (Gegenfurtner and Hagenauer, 2013). Also, organizational support can be incorporated to evaluate its mediating effect in the relationship.

\section{References}

Alliger, G. M., Tannenbaum, S. I., Bennett, W., Traver, H., and Shotland, A. (1997). A meta-analysis of the relations among training criteria. Personnel psychology, 50(2):341358.

Axtell, C. M., Maitlis, S., and Yearta, S. K. (1997). Predicting immediate and longer-term transfer of training. Personnel Review, 26(3):201-213.

Baldwin, T. T. and Ford, J. K. (1988). Transfer of training: A review and directions for future research. Personnel psychology, 41(1):63-105.

Baron, R. M. and Kenny, D. A. (1986). The moderatormediator variable distinction in social psychological research: Conceptual, strategic, and statistical considerations. Journal of personality and social psychology, 51(6):1173.

Bates, T. (2007). Strategic planning for e-learning in a polytechnic. In Making the transition to e-learning: Strategies and issues, pages 47-65. IGI Global.

Becker, G. M., DeGroot, M. H., and Marschak, J. (1964). Measuring utility by a single-response sequential method. Systems Research and Behavioral Science, 9(3):226-232.

Bhatti, M. and Kaur, S. (2009). Factors effecting transfer of training: a fresh review. In 12th International Business Information Management Conference (IBIMA), Kuala Lumpur.

Blume, B. D., Ford, J. K., Baldwin, T. T., and Huang, J. L. (2010). Transfer of training: A meta-analytic review. Journal of management, 36(4):1065-1105. 
Burke, C. S., Stagl, K. C., Klein, C., Goodwin, G. F., Salas, E., and Halpin, S. M. (2006). What type of leadership behaviors are functional in teams? a meta-analysis. The leadership quarterly, 17(3):288-307.

Burke, L. A. and Hutchins, H. M. (2007). Training transfer: An integrative literature review. Human resource development review, 6(3):263-296.

Chiaburu, D. S. and Lindsay, D. R. (2008). Can do or will do? the importance of self-efficacy and instrumentality for training transfer. Human Resource Development International, 11(2):199-206.

Clark, M. S. and Mils, J. (1993). The difference between communal and exchange relationships: What it is and is not. Personality and Social Psychology Bulletin, 19(6):684-691.

Dastgeer, G. and ur Rehman, A. (2012). Effectiveness of management development in pakistani corporate sector: Testing the d'netto model. Journal of Management Development, 31(8):740-751.

Gegenfurtner, A. and Hagenauer, G. (2013). Achievement goals and achievement goal orientations in education. International Journal of Educational Research, 61(1):1-4.

Gijbels, D., Raemdonck, I., and Vervecken, D. (2010). Influencing work-related learning: The role of job characteristics and self-directed learning orientation in part-time vocational education. Vocations and Learning, 3(3):239-255.

Grossman, R. and Salas, E. (2011). The transfer of training: what really matters. International Journal of Training and Development, 15(2):103-120.

Harteis, C. and Gruber, H. (2004). Competence-supporting working conditions. Professional learning: Gaps and transitions on the way from novice to expert, pages 251-269.

Holton, E. F., Bates, R. A., Seyler, D. L., and Carvalho, M. B. (1997). Toward construct validation of a transfer climate instrument. Human Resource Development Quarterly, 8(2):95-113.

Kirkpatrick, L. A. and Davis, K. E. (1994). Attachment style, gender, and relationship stability: A longitudinal analysis. Journal of personality and social psychology, 66(3):502.

Kirwan, C. and Birchall, D. (2006). Transfer of learning from management development programmes: testing the holton model. International Journal of Training and Development, 10(4):252-268.

Kontoghiorghes, C. (2001). Factors affecting training effectiveness in the context of the introduction of new technologya us case study. International Journal of Training and Development, 5(4):248-260.

Latham, G. P. and Locke, E. A. (2007). New developments in and directions for goal-setting research. European Psychologist, 12(4):290-300.

Lewalter, D. and Scholta, K. (2009). The impact of goal and feedback treatments on selfdetermined motivation and situational interest in a computer-based learning context. Contemporary motivation research: From global to local perspectives, pages 229-248.
Liebermann, S. and Hoffmann, S. (2008). The impact of practical relevance on training transfer: evidence from a service quality training program for german bank clerks. International Journal of Training and Development, 12(2):74-86.

Lim, D. H. and Johnson, S. D. (2002). Trainee perceptions of factors that influence learning transfer. International journal of training and development, 6(1):36-48.

March, J. G. and Olsen, J. P. (1998). The institutional dynamics of international political orders. International organization, 52(4):943-969.

Montesino, M. U. (2002). Strategic alignment of training, transfer-enhancing behaviors, and training usage: A posttraining study. Human Resource Development Quarterly, 13(1):89-108.

Nikandrou, I., Brinia, V., and Bereri, E. (2009). Trainee perceptions of training transfer: an empirical analysis. Journal of European Industrial Training, 33(3):255-270.

Noe, R. A. and Schmitt, N. (1986). The influence of trainee attitudes on training effectiveness: Test of a model. Personnel psychology, 39(3):497-523.

Salas, E. and Stagl, K. C. (2009). Design training systematically and follow the science of training. Handbook of Principles of Organizational Behavior: Indispensable Knowledge for Evidence-Based Management, 2nd edn (Chichester: John Wiley $\mathcal{E}$ Sons), pages 59-84.

Schwab, K., Sala-i Martin, X., et al. (2010). The global competitiveness report 2010-2011. World Economic Forum Geneva.

Segers, M. and Gegenfurtner, A. (2013). Transfer of training: New conceptualizations through integrated research perspectives. Educational Research Review, 8:1-4.

Sekaran, U. and Bougie, R. (2010). (2010). Research methods for business: A skill building approach. Wiley.

Tharenou, P., Saks, A. M., and Moore, C. (2007). A review and critique of research on training and organizational-level outcomes. Human Resource Management Review, 17(3):251273.

Van Eerde, W., Simon Tang, K., and Talbot, G. (2008). The mediating role of training utility in the relationship between training needs assessment and organizational effectiveness. The International Journal of Human Resource Management, 19(1):63-73.

Vroom, V. H. (1964). Work and motivation. new york: John willey \& sons. Inc. VroomWork and Motivation1964.

Xiao, X., Li, J., and Samulski, R. J. (1996). Efficient longterm gene transfer into muscle tissue of immunocompetent mice by adeno-associated virus vector. Journal of virology, 70(11):8098-8108. 